\title{
Kata Kerja Transitif dan Intransitif dalam Bahasa Arab dan Bahasa Indonesia (Studi Linguistik Kontrastif)
}

\author{
Izzudin Mustafa, Tubagus Kesa Purwasandy, Isop Syafe'i \\ UIN Sunan Gunung Djati Bandung \\ izzuddin@uinsgd.ac.id, purwasandy@gmail.com, isop.syafei@uinsgd.ac.id
}

Article History:
Received:
24-05-2020
Revised:
16-06-2020
Accepted:
30-06-2020
Keywords:
Transitif, Intransitif, Linguistik
Kontrastif

Article History:

Received:

24-05-2020

Revised:

Accepted:

30-06-2020

\section{Transitif, Intransitif, Linguistik Kontrastif}

\begin{abstract}
:
This research aims to determine contrastive linguistic, transitive dan intransitive verb in arabic language and Indonesian language, and to determine similarities and differences between both of them. This research uses descriptive analytic method with contrastive linguistic approach. Subject of this research is contrastive linguistic contrastive theory and transitive and intransitive verb. Data collection technique is carried out through documentation studies, while the data analysis technique is done by selecting the data obtained, then collected for analysis and conclusions. The results of this research are the contrastive linguistic is method for analyzing language to find similarities and differences in order to find principles that can be applied practically. In Arabic and Indonesian language, transitive verb is verb that has objects and complement, while intransitive verb is verb that does not have objects and complement. The equation between the two is that both languages have one-object and two-object transitive verb, while the difference is that Indonesian bas semitransitive sentence type but Arabic language does not bave, Arabic language bas three-object verb but Indonesian language does not have, Arabic language has different between transitive verb and preposition but Indonesian language does not have.
\end{abstract}

\section{Pendahuluan}

Bahasa merupakan bunyi-bunyi yang digunakan setiap orang untuk mengungkapkan maksud dan tujuan ${ }^{1}$. Karenanya bahasa merupakan alat komunikasi yang berupa sistem lambang bunyi yang dihasilkan alat ucap manusia ${ }^{2}$. Bahasa terdiri atas kata-kata atau kumpulan kata, masing-masing mempunyai makna, yaitu; hubungan abstrak antara kata sebagai lambang dengan objek atau konsep yang diwakili kumpulan kata atau kosakata ${ }^{3}$. Pada waktu kita berbicara atau menulis, kata-kata yang kita ucapkan atau kita tulis tidak tersusun begitu saja, melainkan mengikuti aturan yang ada. Untuk mengungkapkan gagasan, pikiran atau perasaan, kita harus

\footnotetext{
${ }^{1}$ Tri Wiratno and Riyadi Santosa, "Bahasa, Fungsi Bahasa, Dan Konteks Sosial," Pengertian Bahasa, 2015.

2 A Hassan Azahari, "Sejarah Dan Asal-Usul Bahasa Arab: Satu Kajian Linguistik Sejarah,” Pertanika Journal of Social Sciences \& ..., 2004.

${ }^{3}$ DAMAN HURI, "Penguasaan Kosakata Kedwibahasaan Antara Bahasa Sunda Dan Bahasa Indonesia Pada Anak-Anak (Sebuah Analisis Deskriptif-Komparatif)," Jurnal Pendidikan Unsika, 2014.
} 
memilih kata-kata yang tepat dan menyusun kata-kata itu sesuai dengan aturan bahasa ${ }^{4}$.

. Bahasa dipelajari atau dikaji oleh disiplin ilmu yang disebut linguistik atau ilmu bahasa ${ }^{5}$. Secara sederhana, ilmu linguistik berarti studi bahasa secara ilmiah. Definisi ini menyiratkan bahwa studi-studi bahasa itu bersifat objektif, tidak subjektif ${ }^{6}$. Objektivitas bahasa ini telah mendorong tergalinya banyak fakta, ditemukannya banyak metode, terciptanya iklim ilmiah di antara para ahli bahasa di seluruh dunia, juga memberi kesempatan besar kepada para ahli dari berbagai bahasa untuk saling membantu dan berbagi pengalaman.

Ilmu Linguistik, sejak pertumbuhannya pada abad ke-19 hingga sekarang, memiliki beberapa metode kajian, yaitu linguistik komparatif, linguistik deskriptif, linguistik historis, dan linguistik kontrastif?

Linguistik komparatif mengkaji beberapa bahasa yang berasal dari rumpun yang sama untuk diperbandingkan. Linguistik komparatif merupakan metode kajian modern yang paling tua. Dengan linguistik komparatif ini, dunia penelitian bahasa mencapai puncaknya pada abad ke-19. Kajian lingustik komparatif bersandar pada adanya klasifikasi jelas berbagai bahasa ke dalam rumpun-rumpun bahasa tertentu ${ }^{8}$. Cara kerja linguistik komparatif adalah dengan membandingkan kesamaan-kesamaan antar bahasa sehingga diketahui bahwa bahasa-bahasa tersebut berasal dari rumpun yang sama. Misalnya, bahasa Sansekerta, Yunani, dan Latin memiliki kedekatan kebahasaan dan merujuk kepada akar yang sama yang telah punah.

Linguistik deskriptif mengkaji secara ilmiah sebuah bahasa atau suatu dialek pada waktu dan tempat tertentu. Ini berarti linguistik deskriptif hanya mengkaji suatu tataran bahasa saja? Pada abad ke-19 dan permulaan abad ke-20, para ahli bahasa hanya mengkaji bahasa-bahasa dengan pendekatan komparatif saja. Namun kajian terhadap bahasa pun dapat diarahkan tidak hanya kepada satu bahasa saja, yaitu dengan mengkaji struktur fonologi, morfologi, sintaksis, dan semantik. Para ahli bahasa setelah Saussure mulai mengembangkan metode-metode penelitian terhadap struktur bahasa ${ }^{10}$. Bahkan pada tujuh puluh tahun terakhir minat para ahli terhadap

${ }^{4}$ Zahratun Fajriah, "PENINGKATAN PENGUASAAN KOSAKATA BAHASA ARAB ( MUFRADAT) MELALUI PENGGUNAAN MEDIA KARTU KATA BERGAMBAR (Penelitian Tindakan Pada Siswa Kelas I MI Nurul HakimKediri Lombok Barat Tahun 2015 )," AT) MELALUI PENGGUNAAN MEDIA KARTU KATA BERG AMBAR (Penelitian Tindakan Pada Siswa Kelas I MI Nurul HakimKediri Lombok Barat Tabun 2015) Zhratun, 2015, https://doi.org/10.1109/MRA.2014.2360283.

${ }^{5}$ Heymann Steinthal and Heymann Steinthal, "Linguistik," in Grammatik, Logik, Und Psychologie, 2015, https://doi.org/10.1017/cbo9781139207225.013.

"Thomas Wagner, "Einführung in Die Germanistische Linguistik," Informationen Deutsch Als Fremdsprache, 2017, https://doi.org/10.1515/infodaf-2004-2-367.

${ }^{7}$ Misdawati Misdawati, “Analisis Kontrastif Dalam Pembelajaran Bahasa,” 'A Jamiy : Jurnal Bahasa Dan Sastra Arab, 2019, https://doi.org/10.31314/ajamiy.8.1.53-66.2019.

${ }^{8}$ Dewi Pusposari, "Kajian Linguistik Historis Komparatif Dalam Sejarah Perkembangan Bahasa Indonesia," Jurnal Inovasi Pendidikan, 2017.

${ }_{9}^{9}$ Mohammad Baihaqi Hasni and Farah Hanan Aminallah, "Analisis Kontrastif Dalam Penggunaan Gender (المذكر و المؤنث(,"Journal of Global Business and Social Entrepreneurship (GBSE), 2017.

10 Suhardi, "Menguak Linguistik Pendidikan," in PIBSI XXXIX, 2017. 
kajian deskriptif semakin meningkat. Lalu lahirlah berbagai aliran yang kesemuanya kembali kepada dasar-dasar yang sama yang ditemukan oleh Saussure. Linguistik deskriptif mendominasi mayoritas orang-orang yang menyibukkan diri dengan meneliti bahasa. Bahkan, ketika sebagian mereka membahas tentang linguistik modern, maka yang mereka maksud adalah linguistik deskriptif, seolah-olah ia adalah metode kajian satu-satunya dalam linguistik ${ }^{11}$.

Linguistik historis mengkaji perkembangan sebuah bahasa lintas masa. Dengan ungkapan yang lebih spesifik, ia mengkaji perubahan sebuah bahasa lintas masa. Namun ada para ahli yang menolak istilah "perkembangan". Sebab, kata ini mengandung makna peningkatan atau perubahan ke arah yang lebih baik. Sedangkan ini merupakan pandangan preskriptif yang tentu tidak mungkin diterapkan pada perubahan kebahasaan. Mereka memandang tidak ada bentuk bahasa yang lebih baik dari bentuk lainnya. Oleh karena itu, mereka lebih menyukai istilah “deskriptif", yang terjadi hanyalah sebuah perubahan, bukan perkembangan ${ }^{12}$.

Linguistik kontrastif merupakan cabang paling muda dari linguistik. Kajian ini tumbuh setelah perang dunia II. Linguistik kontrastif didasarkan kepada pemikiran sederhana yang tidak diragukan lagi bahwa orang-orang yang belajar atau mengajarkan bahasa asing pasti mengetahuinya ${ }^{13}$. Kesulitan-kesulitan yang dihadapi seseorang yang mempelajari sebuah bahasa baru disebabkan terutama oleh perbedaan-perbedaan antara bahasa asing ini dengan bahasa ibu. Bahasa ibu atau bahasa pertama adalah bahasa yang digunakan seseorang sejak lahir. Bahasa ini didapatkannya dari lingkungan dan dari interaksinya bersama keluarga dan orang sekitar. Sebaliknya, bahasa kedua adalah bahasa yang didapatkan seseorang setelahnya. Bahasa kedua mencakup semua bahasa asing yang didapatkan seseorang dalam tahap-tahap belajarnya atau melalui interaksi langsungnya bersama para penutur bahasa tersebut. Meski sama-sama membandingkan dua bahasa, namun ada perbedaan antara linguistik komparatif dengan linguistik kontrastif. Linguistik komparatif membandingkan bahasa-bahasa yang berpangkal kepada satu rumpun Bahasa, aspek yang dituju kajian ini adalah aspek sejarah. Sedangkan linguistik kontrastif tidak berhubungan dengan aspek sejarah. Studi-studinya memiliki tujuan praktis dalam mengajarkan bahasa ${ }^{14}$.

Ditinjau dari segi objeknya, linguistik komparatif membandingkan bahasa-bahasa yang berasal dari satu rumpun yang sama guna mengetahui bahasa yang menjadi sumber dari bahasabahasa ini, karenanya linguistik ini bercorak historis. Adapun linguistik kontrastif

\footnotetext{
${ }^{11}$ Misdawati Misdawati, “Analisis Kontrastif Struktur Kalimat Bahasa Arab Dan Bahasa Bugis,” Diwan : Jurnal Bahasa Dan Sastra Arab, 2018, https://doi.org/10.24252/diwan.v4i2.5593.

12 La Ino, "Pemanfaatan Linguistik Historis Komparataif Dalam Pemetaan Bahasa-Bahasa Nusantara," RETORIKA: Jurnal Ilmu Bahasa, 2015, https:/ / doi.org/10.22225/jr.1.2.41.365-378.

${ }^{13}$ Mei Feng Kang et al., "Analisis Kontrastif Daripada Aspek Fonologi Antara Bahasa Jepun Dan Bahasa Mandarin Dalam Sebutan Nombor," Journal of Global Business and Social Entrepreneurship (GBSE), 2017, https://doi.org/10.1002/anie.200503600.

14 Misdawati, "Analisis Kontrastif Dalam Pembelajaran Bahasa."
} 
membandingkan bahasa-bahasa baik dari rumpun yang sama maupun rumpun yang berbeda. Tujuan dari linguistik ini adalah untuk mengetahui perbedaan-perbedaan pada tataran fonologi, morfologi, sintaksis, maupun semantik ${ }^{15}$.

Linguistik kontrastif sangat membantu dalam mempelajari atau mengajarkan bahasa baru bagi penutur. Sebab, dengan analisis kontrastif, perbedaan-perbedaan yang sering menjadi penghambat pembelajaran bahasa asing dapat diketahui. Fungsi linguistik kontrastif terlihat dari manfaatnya dalam menentukan dan membangun bahan-bahan ajar yang akan disampaikan dalam pengajaran bahasa asing ${ }^{16}$. Linguistik kontrastif ini akan memudahkan para guru yang berpengalaman untuk meramalkan keberhasilan yang dapat diterima akal sehat dan bagian-bagian struktur bahasa mana yang akan menimbulkan kesukaran-kesukaran terbesar bagi para pelajar.

Kajian linguistik kontrastif dapat diterapkan pada semua tataran bahasa, baik fonologi, morfologi, sintaksis, maupun semantik ${ }^{17}$. Namun pada penelitian ini akan difokuskan pada tataran sintaksis, yaitu perbandingan kata kerja transitif dan intransitif dalam bahasa Arab dan bahasa Indonesia, sehingga dengan demikian diharapkan dapat dijabarkan persamaan dan perbedaanya antara keduanya.

\section{Metode}

Penelitian ini menggunakan metode deskriptif analitik dengan pendekatan linguistik kontrastif $^{18}$. Subjek penelitiannya adalah teori linguistik kontrastif dan kata kerja transitif intransitif. Sumber datanya adalah berbagai dokumen baik buku, artikel, maupun jurnal ilmiah yang terkait dengan linguistik kontrastif terutama kata kerja transitif dan intransitif dalam bahasa Arab dan bahasa Indonesia ${ }^{19}$.

Teknik pengumpulan data dilakukan melalui studi dokumentasi. Studi dokumentasi dilakukan melalui berbagai dokumen baik buku, artikel, maupun jurnal ilmiah untuk mendapatkan data yang terkait dengan linguistik kontrastif, kata kerja transitif, dan kata kerja intransitif baik dalam bahasa Arab maupun dalam bahasa Indonesia ${ }^{20}$.

Analisis data dilakukan dengan memilih dan memilah data yang diperoleh, kemudian dikumpulkan untuk dianalisis dan diambil kesimpulan. Data yang telah dikumpulkan dengan

15 Tri Wiratno, Pengantar Ringkas Linguistik Sistemik Fungsional, Pengantar Ringkas Linguistik Sistemik. Fungsional, 2018, https://doi.org/10.1017/CBO9781107415324.004.

16 Cover Depan, “LINGUISTIK INDONESIA,” Linguistik Indonesia, 2019, https://doi.org/10.26499/li.v37i1.94.

${ }^{17}$ Roman Jakobson, "Linguistik Und Poetik," in Sprachwissenschaft, 2019, https://doi.org/10.1515/9783110588972-016.

${ }^{18}$ MSi. Prof. Dr. Suryana, "Metodologi Penelitian : Metodologi Penelitian Model Prakatis Penelitian Kuantitatif Dan Kualitatif," Universitas Pendidikan Indonesia, 2012, https://doi.org/10.1007/s13398-014-0173-7.2.

${ }^{19}$ Farida Nugrahani, "Metode Penelitian Kualitatif:Dalam Penelitian Pendidikan Bahasa," Surakarta: Universitas Sebelas Maret Press., 2014.

20 Prof.Dr. Sugiyono, metode penelitian kuantitatif, kualitatif,dan R\&D, Alfabeta, cv. (2016). 
lengkap, selanjutnya diolah dan dianalisis untuk menjawab masalah penelitian ${ }^{21}$. Tahap-tahap pengolahan data adalah ${ }^{22}$; Pertama pengumpulan. Dalam tahap ini penulis mengumpulkan data tentang linguistik kontrastif, kata kerja transitif, dan kata kerja intransitif baik dalam bahasa Arab maupun dalam bahasa Indonesia. Data yang sudah terkumpul kemudian disusun, sehingga berbentuk rangkaian teori dan informasi yang bermakna sesuai dengan masalah penelitian. Kedua reduksi data. Pada tahap ini penulis melakukan pengelompokan terhadap teori dan informasi penting yang terkait dengan linguistik kontrastif, kata kerja transitif, dan kata kerja intransitif baik dalam bahasa Arab maupun dalam bahasa Indonesia sesuai topik masalah. Ketiga Analisis. Pada tahap ini penulis memberikan gambaran data hasil penelitian untuk melakukan pengambilan kesimpulan dalam rangka menjawab tujuan penelitian. Keempat penyajian data. Data yang telah dianalisis, kemudian diinterpretasikan berdasarkan hasil data yang didapatkan. Kelima penarikan kesimpulan. Pada tahap ini penulis melakukan pengambilan kesimpulan berdasarkan susunan narasi yang telah disusun pada tahap ketiga, sehingga dapat memberi jawaban atas masalah penelitian.

\section{Hasil dan Pembahasan}

\section{Linguistik Kontrastif}

Linguistik mempelajari bahasa dengan dengan berbagai aspek, baik berupa bunyi bahasa (fonologi), pembentukan kata (morfologi), susunan kata (sintaksis), maupun makna bahasa (semantik). Fonologi adalah bidang linguistik yang membahas tentang bunyi ${ }^{23}$. Fonologi merupakan cabang dari linguistik umum. Cabang linguistik ini hanya menyelidiki bahasa lisan, tidak berhubungan dengan bentuk bahasa lainnya ${ }^{24}$. Morfologi adalah ilmu yang menyelidiki struktur kata, bagianbagiannya, serta cara pembentukannya. Kata menjadi materi dasar yang dipelajari ilmu ini ${ }^{25}$. Sintaksis merupakan aspek linguistik yang disebut dengan tata bahasa atau gramatika yang menempatkan kata menjadi kelompok kata atau kalimat ${ }^{26}$. Morfologi dan Sintaksis merupakan aspek yang tidak dapat dipisahkan satu sama lain, karenanya munculah istilah morfosintaksis. Jika morfologi membicarakan struktur internal bahasa, maka sintaksis membicarakan kata dalam

${ }^{21}$ Ninit Alfianika, "Metode Penelitian Pengajaran Bahasa Indonesia," in Metode Penelitian Pengajaran Babasa Indonesia, 2018. Media, 2014.

${ }^{22}$ Ivanovich Agusta, “Teknik Pengumpulan Dan Analisis Data Kualitatif,” Jurnal Studi Komunikasi Dan

${ }^{23}$ Steinthal and Steinthal, "Linguistik."

${ }^{24}$ Ahmad Suherman, "Perubahan Fonologis Kata-Kata Serapan Bahasa Sunda Dari Bahasa Arab: Studi Kasus Pada Masyarakat Sunda Di Jawa Barat, Indonesia,” Sosiobumanika, 2012.

${ }^{25}$ Febyana Ramadhanti, Yudi Wibisono, and Rosa Ariani Sukamto, “Analisis Morfologi Untuk Menangani Out-of-Vocabulary Words Pada Part-of-Speech Tagger Bahasa Indonesia Menggunakan Hidden Markov Model,” Jurnal Linguistik Komputasional (JLK), 2019, https:/ / doi.org/10.26418/jlk.v2i1.13.

${ }^{26}$ Raja Rachmawati, “ASPEK LINGUISTIK DAN KEBERTERIMAAN DALAM PENERJEMAHAN,” Madab: Jurnal Babasa Dan Sastra, 2017, https://doi.org/10.31503/madah.v5i1.527. 
hubungannya dengan kata lain, atau unsur-unsur lain sebagai suatu satuan ujaran. Sedangkan semantik merupakan penyelidikan makna bahasa, baik yang bersifat leksikal, gramatikal, maupun kontekstual. Makna bahasa merupakan hubungan yang terjalin karena bersatunya dua unsur hubungan kebahasaan.

Linguistik Kontrastif adalah metode sinkronis dalam analisis bahasa untuk menunjukkan persamaan dan perbedaan antara bahasa-bahasa atau dialek-dialek untuk mencari prinsip yang dapat diterapkan untuk masalah yang praktis, seperti pengajaran bahasa dan penerjemahan. Linguistik kontrastif dikembangkan dan dipraktikkan sebagai suatu aplikasi linguistik struktural dalam pengajaran bahasa. Itu sebabnya, linguistik kontrastif dapat digunakan untuk mengatasi kesulitan utama dalam belajar bahasa asing dan dapat memprediksi adanya kesulitan sehingga efek-efek interferensi dari bahasa pertama dapat dikurangi.

Menurut Tajudin Nur $^{27}$, linguistik kontrastif berupa prosedur kerja yang merupakan aktivitas atau kegiatan yang membandingkan struktur bahasa pertama dengan struktur bahasa kedua untuk mengidentifikasi perbedaan perbedaan diantara kedua bahasa. Perbedaan-perbedaan yang diperoleh dan dihasilkan melalui analisis kontrastif dapat digunakan sebagai landasan dalam memprediksi kesulitan dalam mempelajari bahasa kedua.

Tajudin $\operatorname{Nur}^{28}$ menyebutkan bahwa ada dua versi hipotesis analisis kontrastif, yaitu hipotesis bentuk kuat (strong form hypothesis) dan hipotesis bentuk lemah (weak form hypothesis). Pada hipotesis bentuk kuat, semua kesalahan dalam bahasa kedua dapat diprediksi dengan mengidentifikasi perbedaan antara bahasa pertama dan bahasa kedua yang dipelajari oleh siswa. Sedangkan hipotesis bentuk lemah menyatakan bahwa analisis kontrastif dan analisis kesalahan harus saling melengkapi. Analisis kesalahan mengidentifikasi kesalahan dalam korpus bahasa siswa, lalu analisis kontrastif menetapkan kesalahan mana yang termasuk ke kategori yang disebabkan oleh perbedaan bahasa kedua dan bahasa pertama. Menurut Ahmadi Ahmad ${ }^{29}$, biasanya terdapat tiga sumber yang digunakan sebagai penguat dalam hipotesis linguistik kontrastif, yaitu; (a) pengalaman praktis guru bahasa asing, (b) telaah mengenai kontak bahasa dalam situasi kedwibahasaan, dan (c) teori belajar.

Sedangkan linguistik kontrastif setidaknya memiliki tiga tujuan, ${ }^{30}$ yaitu; Pertama, menyelidiki segi-segi perbedaan dan persamaan antar bahasa. Pada aspek ini, analisis kontrastif perlu dilakukan karena setiap bahasa memiliki ciri khas dan keunikan tersendiri. Hal ini seringkali

\footnotetext{
${ }^{27}$ Tajudin Nur, “ANALISIS KONTRASTIF DALAM STUDI BAHASA,” Arabi: Journal of Arabic Studies, 2016, https://doi.org/10.24865/ajas.v1i2.11.

${ }^{28}$ Nur.

${ }^{29}$ Ahmadi Ahmadi, “ANALISIS KONTRASTIF DAN ANALISIS KESALAHAN DALAM PEMBELAJARAN BAHASA ARAB SEBAGAI SECOND LANGUAGE,” At-Tajdid: Jurnal Imu Tarbiyah, 2014. 30 "ANALISIS KONTRASTIF BAHASA INDONESIA DAN BAHASA ARAB BERDASARKAN KALA, JUMLAH, DAN PERSONA," Jurnal Sastra Indonesia (Semarang), 2013.
} 
menjadi kesulitan yang menghambat orang yang ingin mempelajari bahasa asing. Oleh karena itu, penggalian segi-segi perbedaan dan persamaan antara bahasa menjadi tujuan pertama linguistik kontrastif. Kedua, memperkirakan kesulitan-kesulitan yang timbul ketika mengajarkan bahasa asing dan berusaha menjelaskan berbagai kesulitan. Tujuan ini muncul dari hipotesis bahwa kesulitankesulitan mempelajari bahasa asing berbanding lurus dengan besarnya perbedaan antara bahasa ibu pembelajar dan bahasa asing yang hendak dipelajarinya. Sebab, semakin besar perbedaan antara keduanya semakin banyak pula kesulitan yang dihadapinya. Sehingga, ketika kita mengetahui tabiat perbedaan ini, kita dapat memperkirakan kesulitan-kesulitan yang akan muncul ketika proses pembelajaran. Dengan demikian kita juga dapat menjelaskan tabiat kesulitan-kesulitan ini. Ketiga, berpartisipasi dalam mengembangkan materi-materi ajar untuk mengajarkan bahasa asing. Tujuan ini merupakan akibat alami dari kedua tujuan sebelumnya. Jika kita telah berhasil sampai pada deskripsi kontrastif sistemsistem kedua bahasa dan menentukan kesulitan-kesulitan belajar yang telah kita perkirakan berdasarkan deskripsi ini, kita dapat 'mengembangkan' materi-materi ajar untuk menghadapi kesulitan-kesulitan ini.

\section{Kata Kerja Transitif dan Intransitif dalam Bahasa Arab dan Bahasa Indonesia}

Dalam bahasa Arab, kata kerja transitif disebut dengan fi'il muta'addi. Sedangkan kata kerja intransitif disebut dengan fi'il larim. Fi’il muta'addi adalah kata kerja yang dampaknya tidak hanya terasa oleh subjeknya, namun juga dirasakan oleh objek. Misalnya, Fataha Thariq al-Andalus (Thariq membebaskan Andalusia). Sedangkan fi'il lazim adalah kata kerja yang dampaknya hanya terasa oleh subjek saja, tidak dirasakan oleh objeknya. Misalnya, Drahaba Sa’id (Sa’id pergi). ${ }^{31}$

Dengan demikian, fi'il muta'addi merupakan kata kerja yang membutuhkan subjek sekaligus objek. Sedangkan fíil laz̧im hanya membutuhkan subjek. Nama lain dari fi'il muta'addi adalah fi'il waqi' dan fi'il mujawiz. Sedangkan nama lain dari fi'il laz̧im adalah fi'il qashir atau fi'il ghair mujawiz. ${ }^{32}$

Dari segi berdampak langsung atau tidak terhadap objeknya, fi'il muta'addi terbagi menjadi dua jenis, yaitu; (a) muta'addi bi nafsih adalah kata kerja yang langsung berdampak pada objeknya, tanpa bantuan harf jarr (preposisi). Misalnya, Baraytu alqalam (Saya menyerut pensil), (b) fi'il muta'addi bi ghairih adalah kata kerja yang membutuhkan bantuan harf jarr untuk sampai kepada objeknya. Misalnya, Addu al-amanah ila abliba (Sampaikanlah amanah kepada pemiliknya. ${ }^{33}$

31 Ana Rahmawati, "BENTUK INTERFERENSI SINTAKSIS BAHASA INDONESIA DALAM

BERBAHASA ARAB,” Ijaz. Arabi Journal of Arabic Learning, 2018, https://doi.org/10.18860/ijazarabi.v1i2.5416.

32 Rahmawati.

33 Pangadilan Rambe, “Analisis Kemampuan Mahasiswa Pendidikan Bahasa Arab Dalam Memahami Bentuk-Bentuk Kosakata (Studi Anilisis Pembelajaran Bahasa Arab Dari Segi Morfologi),” Kutubkhanah, 2016. 
Di samping itu, fi'il muta'addi juga dapat dibagi menjadi beberapa jenis berdasarkan jumlah objeknya, yaitu; fi'il muta'addi berobjek satu, fi'il muta'addi berobjek dua, dan fi'il muta'addi berobjek tiga $^{34}$.

1. Fi'il muta'addi berobjek satu sangat banyak. Misalnya, kataba, akhadza, ghafara, akrama, dan 'azhzhama (menulis, mengambil, mengampuni, menghormati, dan memuliakan).

2. Fi'il muta'addi berobjek dua terbagi pula menjadi dua jenis, yaitu fi'il muta'addi berobjek dua yang keduanya bukan berasal dari mubtada' dan khabar, serta fi'il muta'addi berobjek dua yang keduanya berasal dari mubtada' dan khabar. Jenis pertama misalnya, a'tha, sa'ala, manaha, kasa, albasa, dan 'allama (memberi, meminta, memberi, memakaikan, memakaikan, dan mengajarkan). Fi'il muta'addi jenis kedua ini terbagi lagi menjadi dua jenis, yaitu:

a. Af'al al-qulub, yaitu kata kerja transitif berobjek dua yang berkaitan dengan kesadaran batin. Misalnya, ra`a, 'alima, dara, wajada, alfa, ta'allam, hab, zhanna, khala, hasiba, ja'ala, dan za'ama (berpendapat, mengetahui, mengetahui, mendapati, mendapati, ketahuilah, anggaplah, mengira, mengira, mengira, menjadikan, dan mengklaim).

b. Af'al at-tabwil, yaitu kata kerja transitif berobjek dua yang berarti 'menjadikan'. Misalnya, shayyara, radda, taraka, takhidza, ittakhadra, ja'ala, dan wahaba. Semua kata kerja ini berarti 'menjadikan'.

3. Fi'il muta'addi berobjek tiga. Fi'il-fi'il muta'addi yang memiliki objek tiga adalah ara, a'lama, anba'a, nabba'a, akbbara, khabbara, dan haddatsa (memperlihatkan, memberitahu, memberitahu, memberitahu, memberitahu, memberitahu, dan memberitahu). ${ }^{25}$

Sedangkan dalam bahasa Indonesia, jenis predikat menentukan jenis kalimat tempat predikat tersebut berada. Jika predikat sebuah kalimat merupakan kata kerja, maka kalimat tersebut dinamakan kalimat verbal. Sedangkan jika predikatnya selain kata kerja, maka ia dinamakan kalimat nominal. Dengan demikian, berdasarkan predikat yang membentuknya, kalimat dapat dibedakan menjadi dua bagian, yaitu kalimat nominal dan kalimat verbal. ${ }^{35}$

Selanjutnya, kalimat verbal dibedakan atas kalimat berkatakerja transitif dan kalimat berkatakerja intransitif. Di antara keduanya dapat dimunculkan pula kalimat berkatakerja semitransitif. Kalimat berkatakerja transitif dibagi lagi menjadi dua, yaitu kalimat berpredikat kata kerja ekatransitif (hanya memiliki satu objek) dan kalimat berpredikat kata kerja dwitransitif (memiliki dua objek). ${ }^{36}$

\footnotetext{
${ }^{34}$ Rambe.

35 Aton M. Moeliono Alwi, Soenjono Dardjowidjojo, Hans Lapoliwa, “Tata Bahasa Baku Bahasa Indonesia," Departemen Pendidikan Dan Kebudayaan Republik Indonesia, 1998.

${ }^{36} \mathrm{Ni}$ Km Ayu Sartika Dewi, I Wyn Rasna, and I Nym Seloka Sudiara Jurusan Pendidikan Bahasa dan Sastra Indonesia, "ANALISIS KESALAHAN BAHASA INDONESIA PADA ESAI MAHASISWA JURUSAN PENDIDIKAN BAHASA DAN SASTRA INDONESIA: SEBUAH KAJIAN EJAAN, DIKSI, DAN STRUKTUR," Jurnal Jurusan Pendidikan Bahasa Dan Sastra Indonesia, 2014.
} 
Kalimat berkatakerja intransitif adalah kalimat yang tidak memiliki objek dan pelengkap, hanya memiliki dua unsur fungsi wajib, yaitu subjek dan predikat. Contoh: Ibu sedang berbelanja.

Adapun kalimat berkatakerja semitransitif adalah kalimat yang predikatnya bisa diikuti objek dan bisa pula tanpa diikuti objek. Dengan adanya objek, maka kalimat tersebut maknanya akan semakin jelas, dan tanpa adanya objek pun kalimat tersebut sudah dapat dipahami dengan baik. Akan tetapi, kehadiran objek pada kalimat semitransitif ini akan mengubah bentuk kalimat menjadi kalimat ekatransitif, dan tanpa kehadiran objek dalam kalimat semitransitif akan mengubah bentuk kalimat menjadi kalimat intransitif. Contoh: (a) Ananda sedang menulis, (b) Ananda sedang menulis puisi. ${ }^{37}$

Kalimat berkatakerja transitif adalah kalimat yang predikatnya membutuhkan objek. Kalimat ini terbagi menjadi dua, yaitu kalimat ekatransitif dan kalimat dwitransitif. ${ }^{38}$ Pada kalimat ekatransitif, kalimat yang berobjek dan tidak berpelengkap memiliki tiga unsur wajib, yaitu subjek, predikat dan objek. Contoh: Sopir itu mengemudikan angkot terlalu cepat. Sementara itu, pada kalimat dwitransitif, kalimat terdiri dari subjek, predikat, objek, dan pelengkap. Contoh: Ayah mengirimi kami uang setiap bulan.

\section{Persamaan dan Perbedaan Kata Kerja Transitif dan Intransitif dalam Bahasa Arab dan}

\section{Bahasa Indonesia}

Persamaan kata kerja transitif dan intransitif dalam bahasa Arab dan bahasa Indonesia adalah bahwa dalam bahasa Arab dikenal istilah kata kerja laz̧im dan muta'addi. Kedua jenis kata kerja ini, dalam bahasa Indonesia dapat dipadankan dengan kata kerja intransitif dan transitif. Dengan demikian, teori tentang kedua jenis kata kerja ini sama-sama ada di dalam kedua bahasa ini. Perbedaannya, dalam bahasa Indonesia dikenal juga istilah kata kerja semitransitif.

Dalam bahasa Indonesia, kata kerja transitif terbagi menjadi dua, yaitu ekatransitif, yaitu kata kerja yang memiliki satu objek, dan dwitransitif, yaitu kata kerja yang memiliki dua objek. Dalam bahasa Arab pun kata kerja muta'addi ada yang memiliki satu objek, ada pula yang memiliki dua objek. Perbedaannya, dalam bahasa Arab, kata kerja muta'addi berobjek dua terbagi menjadi kata kerja dengan dua objek yang berasal dari mubtada'- khabar dan dua objek yang berasal dari selain mubtada'-khabar. Perbedaan selanjutnya adalah dalam bahasa Arab terdapat juga kata kerja muta'addi berobjek tiga. Kata kerja berobjek tiga tidak terdapat dalam bahasa Indonesia.

Sedangkan perbedaan kata kerja transitif dan intransitif dalam bahasa Arab dan bahasa Indonesia adalah bahwa dalam bahasa Arab, dibedakan antara kata kerja transitif dengan harf jar

${ }^{37}$ Sintowati Utami, "PEMBELAJARAN ASPEK TATA BAHASA DALAM BUKU PELAJARAN

BAHASA INDONESIA,” AKSIS: Jurnal Pendidikan Babasa Dan Sastra Indonesia, 2017, https://doi.org/10.21009/aksis.010203.

38 Abdul Chaer, Tata Bahasa Praktis Bahasa Indonesia, Rineka Cipta, 2003. 
(preposisi), ini disebut dengan muta'addi ghair sharih, dan kata kerja tanpa harf jar, ini disebut dengan muta'addi sharih. Sedangkan dalam bahasa Indonesia tidak dibedakan antara kata kerja transitif dengan preposisi dan kata kerja transitif tanpa preposisi.

Jika dihubungkan antara muta'addi berobjek satu, dua, dan tiga dengan muta'addi sharih dan ghair sharih, akan muncul varian berikut: a) Kata kerja berobjek satu tanpa harfjar dan kata kerja berobjek satu dengan harfjar, b) Kata kerja berobjek dua yang keduanya tanpa harf jar, kata kerja berobjek dua yang ber-harf jar pada objek pertama dan tanpa harfjar pada objek kedua, juga kata kerja berobjek dua yang ber-harf jar pada kedua objek; c) Kata kerja berobjek tiga tanpa harf jar. Kata kerja berobjek tiga ini seluruhnya tanpa harfjar.

\section{Kesimpulan}

Linguistik kontrastif merupakan metode untuk menganalisis bahasa untuk menemukan persamaan dan perbedaan dalam rangka mencari prinsip yang dapat diterapkan secara praktis. Dalam bahasa Arab, kata kerja transitif disebut dengan fi'il muta'addi. Sedangkan kata kerja intransitif disebut dengan fíil lazim. Dalam bahasa Arab dan bahasa Indonesia, kata kerja transitif adalah kata kerja yang memiliki objek dan pelengkap, sedangkan kata kerja intransitif adalah kata kerja yang tidak memiliki objek dan pelengkap. Persamaan antara keduanya adalah bahwa dalam kedua bahasa tersebut memiliki kata kerja transitif berobjek satu dan dua, sedangkan perbedaannya adalah bahwa dalam bahasa Indonesia terdapat jenis kalimat semitransitif namun dalam bahasa Arab tidak ada, dalam bahasa Arab terdapat kata kerja yang berobjek tiga, namun dalam bahasa Indonesia tidak ada, dalam bahasa Arab terdapat pembedaan kata kerja transitif dengan preposisi, namun dalam bahasa Indonesia tidak ada.

\section{Daftar Pustaka}

Ahmadi, Ahmadi. "ANALISIS KONTRASTIF DAN ANALISIS KESALAHAN DALAM PEMBELAJARAN BAHASA ARAB SEBAGAI SECOND LANGUAGE.” At-Tajdid : Jurnal Ilmu Tarbiyah, 2014.

Alfianika, Ninit. “Metode Penelitian Pengajaran Bahasa Indonesia.” In Metode Penelitian Pengajaran Bahasa Indonesia, 2018.

Alwi, Soenjono Dardjowidjojo, Hans Lapoliwa, Aton M. Moeliono. "Tata Bahasa Baku Bahasa Indonesia." Departemen Pendidikan Dan Kebudayaan Republik. Indonesia, 1998.

"ANALISIS KONTRASTIF BAHASA INDONESIA DAN BAHASA ARAB BERDASARKAN KALA, JUMLAH, DAN PERSONA.” Jurnal Sastra Indonesia (Semarang), 2013.

Azahari, A Hassan. "Sejarah Dan Asal-Usul Bahasa Arab: Satu Kajian Linguistik Sejarah." Pertanika Journal of Social Sciences \& ..., 2004.

Chaer, Abdul. Tata Bahasa Praktis Bahasa Indonesia. Rineka Cipta, 2003. 
Depan, Cover. “LINGUISTIK INDONESIA.” Linguistik Indonesia, 2019. https://doi.org/10.26499/li.v37i1.94.

Fajriah, Zahratun. "PENINGKATAN PENGUASAAN KOSAKATA BAHASA ARAB ( MUFRADAT ) MELALUI PENGGUNAAN MEDIA KARTU KATA BERGAMBAR ( Penelitian Tindakan Pada Siswa Kelas I MI Nurul HakimKediri Lombok Barat Tahun 2015 )." AT) MELALUI PENGGUNAAN MEDIA KARTU KATA BERGAMBAR (Penelitian Tindakan Pada Siswa Kelas I MI Nurul HakimKediri Lombok Barat Tabun 2015) Zhratun, 2015. https://doi.org/10.1109/MRA.2014.2360283.

HURI, DAMAN. "Penguasaan Kosakata Kedwibahasaan Antara Bahasa Sunda Dan Bahasa Indonesia Pada Anak-Anak (Sebuah Analisis Deskriptif-Komparatif)." Jurnal Pendidikan Unsika, 2014.

Ino, La. "Pemanfaatan Linguistik Historis Komparataif Dalam Pemetaan Bahasa-Bahasa Nusantara." RETORIKA: Jurnal Ilmu Bahasa, 2015. https://doi.org/10.22225/jr.1.2.41.365-378.

Ivanovich Agusta. “Teknik Pengumpulan Dan Analisis Data Kualitatif." Jurnal Studi Komunikasi Dan Media, 2014.

Jakobson, Roman. “Linguistik Und Poetik.” In Sprachwissenschaft, 2019. https://doi.org/10.1515/9783110588972-016.

Kang, Mei Feng, Syahrina Ahmad, Jamal Rizal Razali, Bahasa Jepun, D A N Bahasa, Mandarin Dalam, Sebutan Nombor, Kang Mei Feng, Syahrina binti Ahmad, and Jamal Rizal Razali. "Analisis Kontrastif Daripada Aspek Fonologi Antara Bahasa Jepun Dan Bahasa Mandarin Dalam Sebutan Nombor." Journal of Global Business and Social Entrepreneurship (GBSE), 2017. https://doi.org/10.1002/anie.200503600.

Km Ayu Sartika Dewi, Ni, I Wyn Rasna, and I Nym Seloka Sudiara Jurusan Pendidikan Bahasa dan Sastra Indonesia. "ANALISIS KESALAHAN BAHASA INDONESIA PADA ESAI MAHASISWA JURUSAN PENDIDIKAN BAHASA DAN SASTRA INDONESIA: SEBUAH KAJIAN EJAAN, DIKSI, DAN STRUKTUR.” Jurnal Jurusan Pendidikan Bahasa Dan Sastra Indonesia, 2014.

Misdawati, Misdawati. "Analisis Kontrastif Dalam Pembelajaran Bahasa.” 'A Jamiy : Jurnal Bahasa Dan Sastra Arab, 2019. https://doi.org/10.31314/ajamiy.8.1.53-66.2019. . "Analisis Kontrastif Struktur Kalimat Bahasa Arab Dan Bahasa Bugis." Diwan : Jurnal Bahasa Dan Sastra Arab, 2018. https://doi.org/10.24252/diwan.v4i2.5593.

Mohammad Baihaqi Hasni, and Farah Hanan Aminallah. "Analisis Kontrastif Dalam Penggunaan Gender (المذكر و المؤنث(." Journal of Global Business and Social Entrepreneurship (GBSE), 2017.

Nugrahani, Farida. "Metode Penelitian Kualitatif:Dalam Penelitian Pendidikan Bahasa." Surakarta: Universitas Sebelas Maret Press., 2014.

Nur, Tajudin. "ANALISIS KONTRASTIF DALAM STUDI BAHASA.” Arabi : Journal of Arabic Studies, 2016. https://doi.org/10.24865/ajas.v1i2.11.

Prof. Dr. Suryana, MSi. "Metodologi Penelitian : Metodologi Penelitian Model Prakatis Penelitian Kuantitatif Dan Kualitatif." Universitas Pendidikan Indonesia, 2012. https://doi.org/10.1007/s13398-014-0173-7.2.

Pusposari, Dewi. "Kajian Linguistik Historis Komparatif Dalam Sejarah Perkembangan Bahasa Indonesia." Jurnal Inovasi Pendidikan, 2017. 
Rachmawati, Raja. “ASPEK LINGUISTIK DAN KEBERTERIMAAN DALAM

PENERJEMAHAN.” Madab: Jurnal Bahasa Dan Sastra, 2017.

https://doi.org/10.31503/madah.v5i1.527.

Rahmawati, Ana. "BENTUK INTERFERENSI SINTAKSIS BAHASA INDONESIA DALAM

BERBAHASA ARAB." Ijaz, Arabi Journal of Arabic Learning, 2018.

https://doi.org/10.18860/ijazarabi.v1i2.5416.

Ramadhanti, Febyana, Yudi Wibisono, and Rosa Ariani Sukamto. "Analisis Morfologi Untuk

Menangani Out-of-Vocabulary Words Pada Part-of-Speech Tagger Bahasa Indonesia

Menggunakan Hidden Markov Model.” Jurnal Linguistik Komputasional (JLK), 2019.

https://doi.org/10.26418/jlk.v2i1.13.

Rambe, Pangadilan. “Analisis Kemampuan Mahasiswa Pendidikan Bahasa Arab Dalam

Memahami Bentuk-Bentuk Kosakata (Studi Anilisis Pembelajaran Bahasa Arab Dari Segi

Morfologi)." Kutubkhanah, 2016.

Steinthal, Heymann, and Heymann Steinthal. "Linguistik." In Grammatik, Logik, Und Psychologie, 2015. https://doi.org/10.1017/cbo9781139207225.013.

Sugiyono, Prof.Dr. metode penelitian kuantitatif, kualitatif,dan R\&D, Alfabeta, cv. (2016).

Suhardi. "Menguak Linguistik Pendidikan.” In PIBSI XXXIX, 2017.

Suherman, Ahmad. "Perubahan Fonologis Kata-Kata Serapan Bahasa Sunda Dari Bahasa Arab: Studi Kasus Pada Masyarakat Sunda Di Jawa Barat, Indonesia.” Sosiobumanika, 2012.

Utami, Sintowati. "PEMBELAJARAN ASPEK TATA BAHASA DALAM BUKU PELAJARAN BAHASA INDONESIA." AKSIS: Jurnal Pendidikan Bahasa Dan Sastra Indonesia, 2017. https://doi.org/10.21009/aksis.010203.

Wagner, Thomas. "Einführung in Die Germanistische Linguistik." Informationen Deutsch Als Fremdsprache, 2017. https://doi.org/10.1515/infodaf-2004-2-367.

Wiratno, Tri. Pengantar Ringkas Linguistik Sistemik Fungsional. Pengantar Ringkas Linguistik Sistemik Fungsional, 2018. https://doi.org/10.1017/CBO9781107415324.004.

Wiratno, Tri, and Riyadi Santosa. "Bahasa, Fungsi Bahasa, Dan Konteks Sosial." Pengertian Bahasa, 2015. 